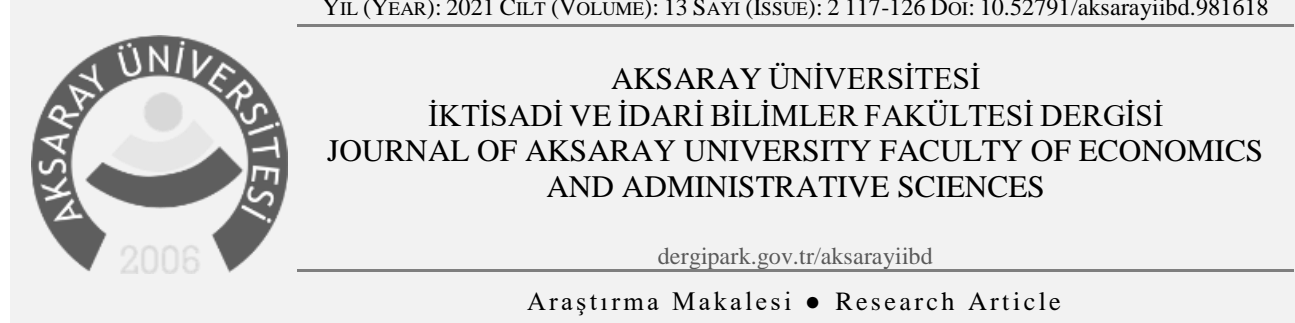

\title{
A Comparative Overview of Mutual Funds, Pension Funds, Real Estate Investment Funds and Venture Capital Investment Funds
}

\author{
Yatırım Fonları, Emeklilik Yatırım Fonları, Gayrimenkul Yatırım Fonları ve Girişim \\ Sermayesi Yatırım Fonlarına Karşılaştırmalı Genel Bakış
}

\author{
Fatih Kayhan $^{1}$, Murat Turgut ${ }^{2}$ ve Mehmet İslamoğlu ${ }^{3}$ \\ ${ }^{I}$ Assistant Prof. Dr., Kirklareli University, fatih.kayhan@klu.edu.tr, Orcid ID: 0000-0001-7844-8663 \\ ${ }^{2}$ Assistant Prof. Dr., Ostim Teknik University, drmuratturgut@ gmail.com, Orcid ID: 0000-0002-0401-4309 \\ ${ }^{3}$ Assoc. Prof. Dr., Karabuk University, mehmetislamoglu@ karabuk.edu.tr, Orcid ID: 0000-0002-4416-0888
}

M A K A L E B İ L G İ İ

Anahtar Kelimeler
Yatırım Fonları
Emeklilik Yatırım Fonlar
Türkiye

JEL Kodları: G20, G23, E44

\author{
Makale Geçmişi: \\ Geliş Tarihi: 11 Ağustos 2021 \\ Kabul Tarihi: 4 Eylül 2021
}

\section{A R T I C LEINFO}

\section{Keywords}

Mutual Funds

Pension Funds

Turkey

JEL Codes: G20, G23, E44

Article History:

Received: 11 August 2021

Accepted: 4 September 2021

\section{Ö ZET}

\begin{abstract}
Çalışmanın amacı, kolektif yatırım kuruluşları kapsamında yer alan yatırım fonları, emeklilik fonları, gayrimenkul yatırım fonları ve girişim sermayesi yatırım fonlarını karşılaştırmalı olarak incelemektir. Çalışmanın veri kaynağı Sermaye Piyasası Kurulu web sitesinde yer alan istatistik bilgileridir. Türkiye ile ilgili olarak, 2015-2021 yılları arası veriler kullanılarak, VAR ve 'Johansen Co-Integration' analizi ve 'Vector-Error Correction Model' ile döviz kurlarının (USD/TL ve EUR/TL) emeklilik yatırım fonlarının ve yatırım fonlarının toplam değeri üzerindeki etkisi incelenmiştir. Bulgular şuna işaret etmektedir; uzun vadede, hem USD/TL hem EUR/TL kurları ile emeklilik yatırım fonları toplam büyüklüğü arasında eşbütünleşme ilişkisi mevcuttur, EUR/TL ile emeklilik fonları varlık büyüklükleri arasındaki ilişki negatif yönlü iken, USD/TL ile pozitif ilişki vardır. Çalışmanın argümanı şudur, Türkiye'de yatırım fonları ve emeklilik yatırım fonları varlık büyüklükleri istikrarlı artış göstermektedir. Sonuç olarak, ileri dönemde, kolektif yatırım kuruluşlarının toplam finansal sektör içerisindeki payının artması
\end{abstract} beklenmektedir.

\begin{abstract}
A B S T R A C T
This study reviews 'collective investment institutions' under Turkish Capital Market Law: Mutual funds, pension funds, real estate investment funds and venture capital investment funds. In this paper, data is retrieved from official website of Capital Market Board. With 'VAR' and 'Johansen Co-Integration analysis' and with 'Vector-Error-Correction Model', the impact of FX rates on net asset values of pension and mutual funds is examined for the period between 2015-2021 in Turkey. Findings indicate that in the long term, there is a co-integration relation between FX rates and net asset values of pension funds. It is argued that net asset values of both pension funds and mutual funds have increased steadily in Turkey despite economic turbulances. This study concludes that significance of funds as collective investment institutions in financial industry will incline further with new products and legislation.
\end{abstract}

$\mathrm{U}$

nder Turkish Capital Markets Law, institutions of capital markets are classified as follows: Intermediary institutions, banks, funds, investment trusts, asset management firms, independent audit firms, real estate appraisal companies.

Banks comprise about $90 \%$ of the total finance system in Turkey. However, lately there has been increase in the proportion of other institutions, especially mutual funds and pension funds have gained importance with respect to volume of asset under management, number of investors. Investment trusts ('IT') ('Yatırım ortaklıkları') together with mutual funds (MFs) ('yatırım fonları') form collective investment institutions ('kolektif yatırım ortaklıkları'). 
Scope of this paper is limited to MFs rather than ITs. This paper specifically covers mutual funds, 'MF' ('yatırım fonları'), pension funds, 'PF' ('Gayrimenkul yatırım fonları'), real estate investment funds, REIF ('gayrimenkul yatırım fonları') and venture capital investment funds, VC funds ('girişim sermayesi yatırım fonları').

Pension Funds are referred as 'Pension Mutual Funds' or 'Pension Investment Fund'): The term is defined by 'Private Pension Savings and Investment system Law (Law No 4632) in Article 12 as follows: The fund is the asset constituted for operation of the contributions collected by the company under the scope of the pension contract and tracked by the participants in their private pension accounts based on risk distribution and fiduciary ownership principles.

Pension funds do not have a legal personality. The fund shall not be used and established except for the purposes defined in this law. According to latest statistics by Pension Monitoring Authority, total funds size of voluntary participation system (IPS) and Auto Enrollment Funds (AES) are about TL 170 billion and TL 13.5 billion successively.

Financial Stability Report by Central Bank of Turkey (2021, May) provides updated figures about the current breakdown of where households in Turkey invest their saving in. This is indicated below in Table 1.

Table 1. Households' Financial Assets (Turkey)

\begin{tabular}{|c|c|c|c|c|c|}
\hline \multicolumn{6}{|c|}{ Breakdown of Financial Assets of Households (Turkey) } \\
\hline & \multicolumn{2}{|c|}{ September, 2020} & \multicolumn{2}{|c|}{ March, 2021 } & \multirow{2}{*}{$\begin{array}{c}\text { Change } \\
\%\end{array}$} \\
\hline & Billion TL & Proportion & Billion TL & Proportion & \\
\hline Total Assets & 2.438 & 100 & 2.682 & 100 & 10 \\
\hline TL Saving Deposit & 820 & 33.6 & 900 & 33.6 & 10 \\
\hline FX Savings Deposit & 820 & 33.6 & 887 & 33.1 & 8 \\
\hline (Billion USD) & 105 & & 107 & & \\
\hline Precious Metal Deposit Acc. & 227 & 9.3 & 258 & 9.6 & 14 \\
\hline (Billion USD) & 29 & & 31 & & \\
\hline Bills and Bonds & 58 & 2.4 & 59 & 2.2 & 1 \\
\hline -Public & 36 & 1.5 & 37 & 1.4 & 3 \\
\hline -Private & 22 & 0.9 & 22 & 0.8 & -2 \\
\hline Funds & 240 & 9.8 & 263 & 9.8 & 10 \\
\hline -Pension Funds (PFs) & 140 & 5.7 & 150 & 5.6 & 8 \\
\hline -Other Mutual Funds (MFs) & 100 & 4.1 & 112 & 4.2 & 12 \\
\hline Stocks & 168 & 6.9 & 239 & 8.9 & 42 \\
\hline Repo & 3.5 & 0.1 & 5.7 & 0.2 & 62 \\
\hline Currency in Circulation & 101 & 4.1 & 71 & 2.6 & -30 \\
\hline
\end{tabular}

Source: Central Bank of Turkey, Central Credit Institution (MKK) and Pension Monitoring Authority.

As can be seen in Table 1, proportion of mutual funds plus pension funds comprise nearly $10 \%$ of financial assets of households in Turkey for the last two years. Comparatively, $10 \%$ increase in funds (mutual funds and pension funds) is observed during Covid-19 period. As of March-2021, total financial assets held by households under 'funds' (mutual funds and pension funds) rank second in Turkey (after TL \& FX deposits).

Venture Capital Invesment Funds-VC Funds: With the help of these funds, one can invest in those companies that have high potential but are not listed (quoted) on the stock market. Another way of saying, these funds make it available for savers to make use of investment opportunities in SME Companies with high potential (of return). It is apparent that activities (entry and exit- number of trades/transactions) of venture capital is increasing. VC funds are invested considerably in global pension funds.

Real Estate Investment Funds-REIF: Funds are issued based on regulations of Capital Markets Authority of Turkey ('CMB' $=$ SPK'). Registrar, Custodian and Fund Manager of these funds are independent, and they are responsible directly to the CMB and legal authorities. Fund assets can not be pledged; also, they cannot be given as collateral. They can't be seized by 3 rd parties. These funds predominantly invest in real estate. Those who invest in this type of funds indirectly invest in real estate (more liquidly), they do not spend time on process for investing directly in real estate, and more importantly, they eliminate costs on real estate purchase and sale transactions.

Motivation of this study is that in contrast to banking industry and other leading instiutions, the number of studies about collective investment institutions are scarce. Capital markets are developing in Turkey and parallel to this very fact, there is an enhancement in alternative financial institutions (and products) like MFs, PFs, REIFs and venture capital investment funds (VC funds).

This paper makes contribution to the literature on these type of collective investment institutions with updated figures and also provides a quantitative analysis regarding the impact of FX rates upon development of these funds. Funds are important in that 
these new institutions and products, especially (private) pension funds, REIF and VC funds are relatively new ones and proporiton of them in total financial system is steadily increasing due to the very young nature and potential of these funds.

The first part is the introduction part. The second section provides quantitative information about the funds. The third part is literature review. Econometric analysis is conducted in the 4th section. The last section, the 5th one, concludes the paper.

\section{MFS, PFS, REIFS AND VENTURE CAPITAL INVESTMENT FUNDS IN FIGURES}

In this part, quantitative information about collective investment institutions are provided to understand the development of MFs, PFs, REIFs and also venture capital investment funds in Turkey. In this part, the term PFs cover both IPS (Voluntary) and AES. Firstly, basic statistical information is given in the following Figures, Figure 1 and 2 . These are provided via Financial Stability Report of Central Bank of Turkey (May 2021 Report).

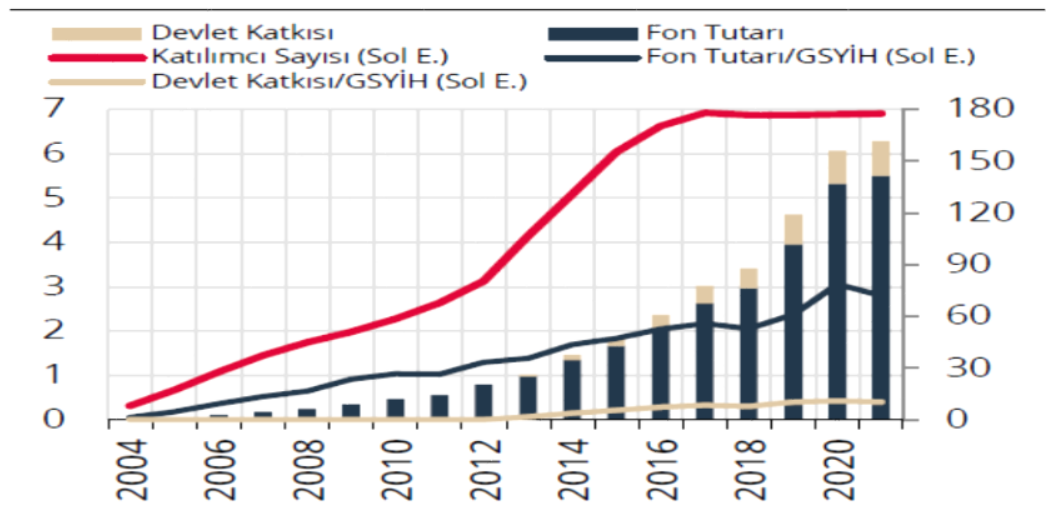

Figure 1. (Voluntary) Private Pension System- IPS (Turkey) (Last Observation: April, 2021)

Source: EGM, CBT

According to the above figure (Pension System of Turkey), 'Devlet Katk1s1' refers to 'state contribution amount' (Billion TL). 'Katılımc1 Sayıs1 (Sol E.)' refers to 'Number of Contributors/Investors (Left Axis) of the system (Million). 'Devlet Katk1s1/GSYIH (Sol E.)' refers to 'State Contribution Amount/GDP (Left Axis)'. 'Fon Tutar1' refers to 'Pension Funds Asset under Management'. And, 'Fon Tutar//GSYIH (Sol E.)' refers to 'PF Asset under Management/GDP (Left Axis)'. As seen from this figure, in Turkey, PFs have been growing steadily since the inception. This is attributable to the very young nature of the system given the fact that Turkey is an emerging economiy with high rate of young popolation. Furthermore, relatively low level of state-run pension benefits that lead to limited purchasing power cause individuals to demand private pension products.

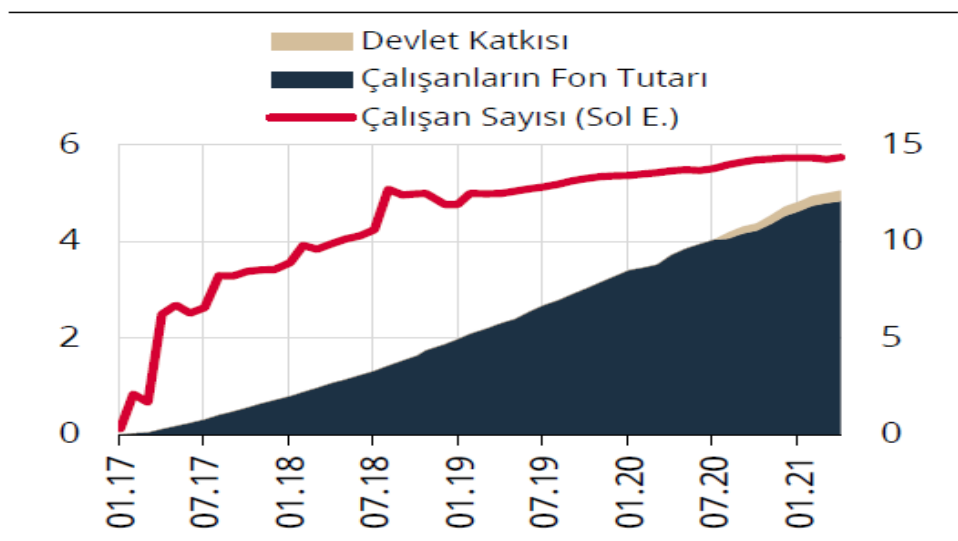

Figure 2. Auto Enrollment System- AES (Turkey) (Last Observation: April, 2021)

Source: EGM, CBT

According to the above figure (Auto Enrollment System of Turkey), 'Devlet Katkısı' refers to 'state contribution amount' (Billion TL). 'Çalışanların Fon Tutarı' refers to 'Amount of Assets paid by Contributors (for AES) in Billion TL. 'Çalışan Sayıs1 (Sol E.)' refers to 'Number of Workers/Employees/Contributors'. As indicated in Figure 2, there is an increasing trend 
in total amount paid for the system by contributors (employees=workers) and also increasing trend in number of contributors. This can be explained by the compulsory nature of the system since entrance to this system is mandatory for workers over a specified age. However, after a short period, exit (from the system) is allowed, therefore a great many workers prefer to quit the system (especially those with low salary/income).

Table 2. Comparative Development of Number of Funds - PFs and MFs (Turkey)

\begin{tabular}{|r|r|r|r|r|r|}
\hline Period & Number of PF & Number of MF & Period & Number of PF & Number of MF \\
\hline 2017_01 & 283 & 389 & $2019 \_01$ & 408 & 489 \\
\hline 2017_02 & 285 & 387 & $2019 \_02$ & 408 & 488 \\
\hline 2017_03 & 287 & 392 & $2019 \_03$ & 408 & 498 \\
\hline 2017_04 & 287 & 367 & $2019 \_04$ & 409 & 503 \\
\hline 2017_05 & 293 & 438 & $2019 \_05$ & 409 & 529 \\
\hline 2017_06 & 293 & 434 & $2019 \_06$ & 409 & 538 \\
\hline 2017_07 & 287 & 430 & $2019 \_07$ & 541 \\
\hline 2017_08 & 289 & 431 & $2019 \_08$ & 548 \\
\hline 2017_09 & 293 & 436 & $2019 \_09$ & 412 & 549 \\
\hline 2017_10 & 293 & 439 & $2019 \_10$ & 412 & 546 \\
\hline 2017_11 & 293 & 442 & $2019 \_11$ & 412 & 552 \\
\hline 2017_12 & 299 & 456 & $2019 \_12$ & 411 & 560 \\
\hline 2018_01 & 387 & 459 & $2020 \_01$ & 409 & 575 \\
\hline 2018_02 & 401 & 459 & $2020 \_02$ & 409 & 597 \\
\hline 2018_03 & 408 & 464 & $2020 \_03$ & 408 & 615 \\
\hline 2018_04 & 403 & 467 & $2020 \_04$ & 407 & 637 \\
\hline 2018_05 & 405 & 470 & $2020 \_05$ & 407 & 649 \\
\hline 2018_06 & 405 & 481 & $2020 \_06$ & 405 & \\
\hline 2018_07 & 405 & 486 & $2020 \_07$ & 405 & 630 \\
\hline 2018_08 & 408 & 483 & $2020 \_08$ & 405 & 636 \\
\hline 2018_09 & 408 & 487 & $2020 \_09$ & 404 & 640 \\
\hline 2018_10 & 408 & 486 & $2020 \_10$ & 404 & 647 \\
\hline 2018_11 & 408 & 489 & $2020 \_11$ & 404 & 604 \\
\hline 2018_12 & 408 & 489 & $2020 \_12$ & & \\
\hline
\end{tabular}

Source: Capital Market Board of Turkey

As illustrated in Table 2, with respect to number of funds, there is a positive trend in both PFs and MFs, however increase in PFs is larger than MFs. Siginificant incline in PFs in 2018 can be explained by introduction of Auto Enrollment Funds (AES).

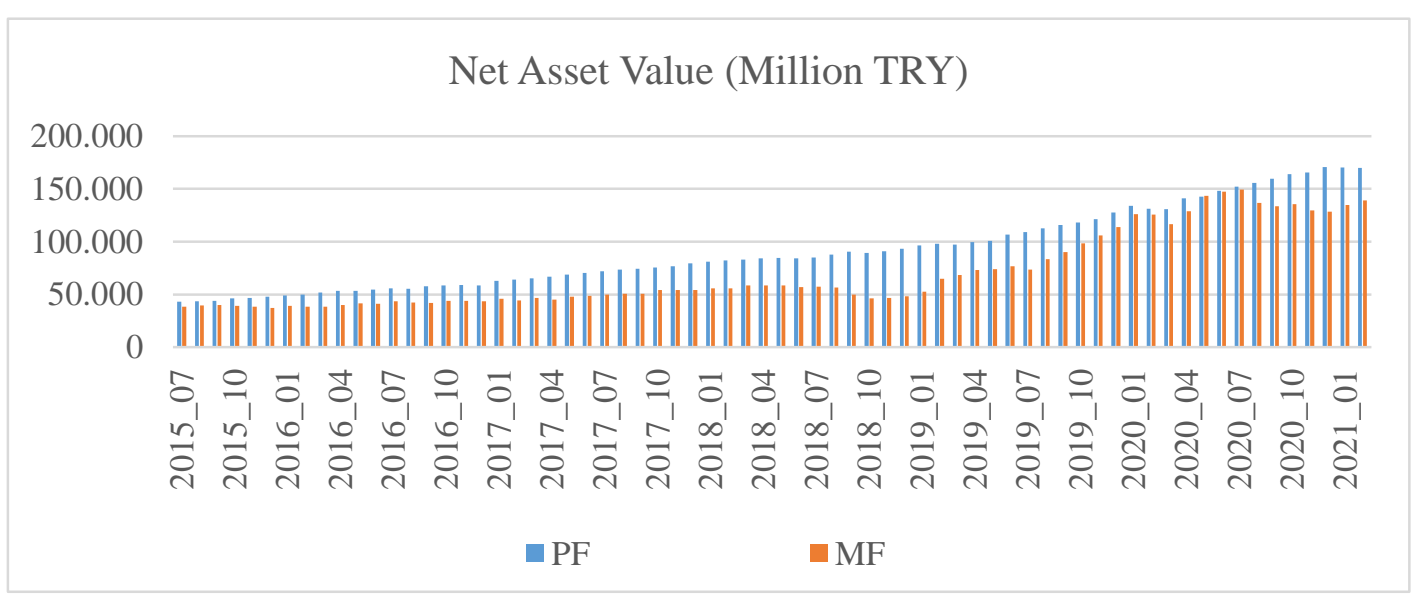

Figure 3. Comparative Development of Net Asset Value - PFs and MFs (Turkey) (Last Observation: April, 2021) Source: Capital Market Board of Turkey

As seen in Figure 3, a positive trend exists in terms of development of net asset values of PFs and MFs. On the other hand, net asset value of PFs is bigger than MFs for the period in question, as opposed this very fact in terms of number of funds, there are more MFs. 
Table 3. Comparative Development of Number of Investors - PFs and MFs (Turkey)

\begin{tabular}{|c|c|c|c|c|c|}
\hline Period & $\mathrm{PF}$ & MF & Period & PF & MF \\
\hline 2017_01 & $6,718,734$ & $3,234,255$ & 2019_01 & $6,841,430$ & $3,172,252$ \\
\hline 2017_02 & $6,743,201$ & $3,220,270$ & 2019_02 & $6,822,902$ & $3,179,827$ \\
\hline 2017_03 & $6,748,008$ & $3,261,604$ & 2019_03 & $6,812,206$ & $2,472,241$ \\
\hline 2017_04 & $6,760,092$ & $3,245,052$ & 2019_04 & $6,816,852$ & $2,557,613$ \\
\hline 2017_05 & $6,791,227$ & $3,286,684$ & 2019_05 & $6,806,690$ & $2,375,669$ \\
\hline 2017_06 & $6,811,854$ & $3,374,232$ & 2019_06 & $6,809,071$ & $2,395,268$ \\
\hline 2017_07 & $6,825,250$ & $3,149,667$ & 2019_07 & $6,794,436$ & $2,380,954$ \\
\hline 2017_08 & $6,831,589$ & $3,376,001$ & 2019_08 & $6,801,993$ & $2,353,190$ \\
\hline 2017_09 & $6,839,860$ & $3,314,885$ & 2019_09 & $6,801,720$ & $2,357,660$ \\
\hline $2017 \_10$ & $6,867,789$ & $3,297,224$ & 2019_10 & $6,814,748$ & $2,441,239$ \\
\hline $2017 \_11$ & $6,898,042$ & $3,357,911$ & 2019_11 & $6,837,963$ & $2,353,247$ \\
\hline 2017_12 & $6,922,615$ & $3,064,461$ & 2019_12 & $6,871,132$ & $2,459,220$ \\
\hline 2018_01 & $6,926,368$ & $3,350,422$ & 2020_01 & $6,883,834$ & $2,312,961$ \\
\hline 2018_02 & $6,949,032$ & $3,417,577$ & 2020_02 & $6,899,702$ & $2,472,488$ \\
\hline 2018_03 & $6,953,410$ & $3,326,173$ & 2020_03 & $6,903,563$ & $2,351,825$ \\
\hline 2018_04 & $6,965,986$ & $3,316,620$ & 2020_04 & $6,878,028$ & $2,471,868$ \\
\hline 2018_05 & $6,977,197$ & $3,566,889$ & 2020_05 & $6,855,636$ & $2,438,302$ \\
\hline 2018_06 & $6,982,994$ & $3,495,178$ & 2020_06 & $6,837,293$ & $2,547,572$ \\
\hline 2018_07 & $6,975,087$ & $3,378,700$ & 2020_07 & $6,844,105$ & $2,529,073$ \\
\hline 2018_08 & $6,974,925$ & $2,887,995$ & 2020_08 & $6,859,900$ & $2,566,870$ \\
\hline 2018_09 & $6,944,094$ & $3,376,037$ & 2020_09 & $6,874,680$ & $2,526,099$ \\
\hline 2018_10 & $6,902,906$ & $3,197,590$ & $2020 \_10$ & $6,888,032$ & $2,527,668$ \\
\hline 2018_11 & $6,883,738$ & $3,227,920$ & 2020_11 & $6,899,464$ & $2,494,704$ \\
\hline $2018 \_12$ & $6,875,886$ & $3,224,020$ & $2020 \_12$ & $6,900,565$ & $2,424,995$ \\
\hline
\end{tabular}

Source: Capital Market Board of Turkey

As shown in Table 3, unlike PFs, there is a downward trend in MFs with regard to number of investors. This indicates that individual pension system and funds are more attractive with long-term advantages and state-contribution-advantage.

Table 4. Comparison of MFs, PFs, REIFs and Venture Capital Investment Funds

\begin{tabular}{|c|c|c|c|c|}
\hline $\begin{array}{c}\text { Collective Investment } \\
\text { Institutions }\end{array}$ & MPs ('YF') & PFs ('EYF') & REIF ('GYF') & $\begin{array}{c}\text { Venture Capital } \\
\text { Investment Funds } \\
\left({ }^{\prime} G S Y F^{\prime}\right) \\
\end{array}$ \\
\hline Established by & $\begin{array}{c}\text { Asset Management } \\
\text { Company }\end{array}$ & Pension Company & $\begin{array}{c}\text { Asset Management } \\
\text { Company }\end{array}$ & $\begin{array}{c}\text { Asset Management } \\
\text { Company }\end{array}$ \\
\hline $\begin{array}{l}\text { Appraisal Period } \\
\text { ('Değerleme Dönemi') }\end{array}$ & Daily & Daily & $\begin{array}{l}\text { (In general) Quarterly, } \\
\text { Semi-Annually or } \\
\text { Annually. } \\
\text { Rarely Monthly. }\end{array}$ & $\begin{array}{c}\text { (In general) Semi-Annually } \\
\text { or Annually. } \\
\text { Rarely Quarterly. }\end{array}$ \\
\hline $\begin{array}{l}\text { Short Term / Long Term } \\
\text { Return Advantage }\end{array}$ & Short term advantage & Long term advantage & Long term advantage & Long term advantage \\
\hline $\begin{array}{l}\text { Managed By } \\
\text { (Portfolio Management) }\end{array}$ & $\begin{array}{c}\text { Asset Management } \\
\text { Company }\end{array}$ & $\begin{array}{c}\text { Asset Management } \\
\text { Company }\end{array}$ & $\begin{array}{c}\text { Asset Management } \\
\text { Company }\end{array}$ & $\begin{array}{c}\text { Asset Management } \\
\text { Company }\end{array}$ \\
\hline $\begin{array}{l}\text { Mostly Demanded By } \\
\text { (Potential Customer Type) }\end{array}$ & $\begin{array}{l}\text { Clients looking for } \\
\text { short-term return }\end{array}$ & $\begin{array}{l}\text { Clients looking for } \\
\text { long-term return }\end{array}$ & $\begin{array}{l}\text { Clients looking for } \\
\text { long-term return }\end{array}$ & $\begin{array}{l}\text { Clients looking for } \\
\text { long-term return }\end{array}$ \\
\hline Portfolio Structure & $\begin{array}{l}\text { Deposit and Capital Market } \\
\text { Instruments } \\
\text { with Fixed and Variable } \\
\text { Return }\end{array}$ & $\begin{array}{l}\text { Deposit and Capital Market } \\
\text { Instruments } \\
\text { with Fixed and Variable } \\
\text { Return }\end{array}$ & $\begin{array}{c}\text { Mostly Real Estate } \\
\text { (plus other investment } \\
\text { tools) }\end{array}$ & $\begin{array}{c}\text { Funds invest in SME } \\
\text { companies that have high } \\
\text { return potential, } \\
\text { innovative investments, } \\
\text { creating positive EBITDA }\end{array}$ \\
\hline $\begin{array}{l}\text { Traded in Stock Exchange } \\
\text { (Listed or not) }\end{array}$ & No & No & $\begin{array}{l}\text { Some of them are listed } \\
\text { (For example, 'ALONE, } \\
\text { ALBTS and ALDUK' ) }\end{array}$ & No \\
\hline
\end{tabular}

Source: Regulations of Capital Market Board of Turkey (Secondary Legislation)

(*) For REIFs and VC funds, in regard to appraisal (evaluation of fund portfolio), number of fund appraisal and fund performance are inversely-related due to appraisal costs; that is, for real estate and company appraisal, a number of costs arise 
(for example, expertise costs.) Especially for REIFs, minimum requirement is one appraisal in a year; at least one appraisal is required.

As can be seen from Table 4, collective investment institutions are alike in that they are all managed by professional (Asset Management Companies). Nevertheless, in terms of establishment, (short \& long term) return advantage, client type, portfolio structure and being listed or not, they have different characteristics. They are all regulated and supervized by Capital Market Board of Turkey.

\section{LITERATURE OVERVIEW}

In this section, some of the previous studies regarding the MFs, PFs, REIFs and venture capital investment funds are analyzed. Before analyzing previous studies, general framework of collective investment instruments should be noted; these instruments are covered under financial system. Financial system carries out the transfer of funds between potential savers, who can basically be grouped in 4 groups in an economy, and investors (households, companies, government and foreigners) who want to borrow, by harmonizing them through financial markets and financial institutions, and by creating new financial instruments (Yay, 2015, s. 19).

For Turkey, given the fact that the collective investment institutions (studied in this paper) are part of financial system and economy, it is necessary to briefly look at financial market in 2020. Turkish Capital Markets 2020 Annual Review Report (2021:6) maintains that because of Covid-19, 2020 was a year of unexpected developments: In the 1st quarter of 2020, global financial markets encountered losses since lockdown measures (for Covid-19) hit global economic activity. In this context, it is also quite helpful to have look at global economic and financial conditions before Covid-19, the global economy has been struggling with growth since the 2008 Financial Crisis, structural problems such as slow growth, aging population, overindebted economy, inelastic supply-demand, weak industrial production, high youth unemployment are becoming 'normal' (Uzunoğlu et al., 2020,136). OECD Report (Pensions Funds in Figures, June 2021) states that PFs assets increased in 2020 despite COVID-19. PFs assets exceeded USD 35 trillion at end-2020, despite the pandemic in (almost) all countries except those countries that encounter significant (early) withdrawals. Equities and bonds constituted about $75 \%$ of pension fund investments on average at end-2020. The outlook for PFs is relatively positive for the first quarter 2021.

Konuralp (2005:49) explains the basic legal feaures of MFs: They don not have legal personality; fund assets are separate from the founder's assets; the responsibility of the founder of the fund is to manage the fund for the account of the participation certificate holders with the same care and in accordance with the risk distribution principle, as if he were managing his own assets ('trusted property basis'). Key features of MFs are explained by Uzunoğlu (2020:31) as follows: The savings of many small and large capital owners are brought together; a uniform portfolio is created for everyone within the framework of risk they can choose; portfolio creation and management is carried out by professionals; brokerage costs are reduced due to portfolio size; the optimal balance between maximum return and minimum risk is targeted.

Samırkaş and Düzakın (2012:391) study performances of MFs (A type and B type funds that are referred as stocks funds and bond funds successively; this caterogy of funds was used before, currently this category is not valid) for the period between 2000 and 2010 via Treynor, Sharpe and Jensen method, and argue that A type funds are competitive than B type funds. Arslan and Arslan (2012:3) study risk-return relations an comparative performances of MFs and cover the period between 2006 and 2010; MANOVA test is applied to determine whether mutual funds returns, ISE 100 index returns and GDBS returns are different from each other; they conclude that significant difference was found between the averages of the returns. Gökgöz and Günel (2012:3) in their study evaluate the performance of investment instruments in the Turkish Capital Market, examine four important financial models (Sharpe Ratio, Sortino Ratio, Treynor Ratio and Jensen's Alpha) covered under the single-criteria performance evaluation models; and argue that single-criteria performance models give significant results in terms of determining the performance of Turkish mutual funds. Gören and Umutlu (2015:603) find out that contrary to the expectations, a great majority of funds evaluated under the control of expenses do not exhibit high performance. Temizel and Bayçelebi (2015:274) emphasize that analyzing the performance of MFs in Turkey gained more importance as a result of the developments in TEFAS; and suggest the data envelopment model. Akgiray et al. (2016:1) argue that pension funds contribute to the reduction of volatility in financial markets by i) having a long-term investment perspective, ii) absorbing the volatility in financial markets by spreading them over the long term, and iii) transferring their investments to the real economy with stock and infrastructure funds. Examining the performance of US MFs that invest primarely in emerging market quities and bonds, Kiymaz and Şimsek (2017:58) find out that diversified emerging market funds generate important alphas for their investors during 2000-2017. However, emerging market bond funds do not generate any important positive alphas; an analysis of sub-period performance suggests that these funds do not consistently generate excess returns, and show considerable differences in different periods.

In regard to objectives of REIFs, Sevindi (2019:7) maintains that the purpose of real estate investment funds is to securitize real estate and make it a liquid investment vehicle; it also enables investors to invest in large-scale real estates that they cannot 
individually finance with their small savings, and thus benefit from the incomes obtained from these investments; in addition, it allows the transfer of investments made in real estate to the capital markets. Edward and Daniel (2000:239) study performances and fund characteristics of REIFs and contend that given the increasing popularity of mutual funds as a way to invest in real estate, questions appear concerning the performance and they calculate the abnormal returns over the three-year period 1996-98 for a sample of twenty-eight real estate funds; they find that, as a group, REIFs do not generate positive abnormal performance and also find that expense ratios, turnover and fund age are all correlated with fund performance.

Regarding venture capital funds (VC Funds), first, a seminal-paper by Zider (1998: 132) about 'how a venture capital works should be mentioned in this section: Zider points out that seperating popular myths and realities (about venture capital) is crucial, contrary to popular belief, VCs play only a minor role in fundind basic innovation. The myth is that venture capitalist invest in good people and good ideas; however, what is real is that they invest in good sectors (Zider, 1998:133). Mayer et al. (2005:586), compare the investment activities and sources of finance of (VC) funds in Germany, Israel, Japan and UK and argue than VC investments vary across countries in regard to their stage, sector and geographical focus; sources of VC funds also differ across countries; although the differences in investments are related to funding sources, a large proportion of variation within as well as between countries is unrelated to sources of finance. They conclude that neither financial systems nor sources of finance are the main explanations for the pronounced differences in VC activities. Cumming and Johan (2009:23) study 17 countries, examine compensation about fixed management fees, performance fees and reduced fees for poor performance, and cash versus share distributions; and then argue that legal conditions have the most robust significant effect on compensation across countries.

Finally, for these funds, portfolio management is necessary. As stated above, the funds are managed by portfolio managers of asset management companies. Nonetheless, apart from this conventional portfolio management type, new channel of portfolio management has become popular with financial technology: Robo-Advise. It was the first stage that portfolio management tools were transferred to the digital environment and investment advisors started to serve their customers using these digital tools; now, without the need for an investment advisor, investors can create their own portfolios and manage them dynamically; robo-advisors who offer this service charge low fees (Sarığlu, 2019:109).

\section{DATA, METHOD, ANALYSIS, FINDINGS}

\subsection{Data and Method}

In this part, the effect of foreign exchange rates (USD/TL and EUR/TL) upon net asset values of mutual funds (YF) and also private pension funds (EYF) is analyzed. Data is retrieved from official website of Capital Market Board of Turkey (monthly statictical bulletin). The period covers the years from 2015 to 2021.

In the very beginning of the study, we have to test whether the series involved in the analysis are stationary or not. Because if we proceed with non-stationary series, they may lead illusory results. So, we must start with performing Augemented Dickey Fuller Unit Root Testing in order to ensure stationarity of the series. Dickey Fuller tests known as $\tau$ - tests and can be conducted allowing for an intercept, or an intercept and deterministic trend or none, in the test regression. The model for unit root test in each case is:

$\mathrm{Yt}=\Phi \mathrm{Yt}-1+\mu+\lambda \mathrm{t}+\mathrm{Ut}$

If the series are stationary at level, we will estimate the models below:

$\mathrm{LNEYF}=\beta 1 \mathrm{USD}+\beta 2 * \mathrm{EURO}+\varepsilon 1$

$\mathrm{LNYF}=\beta 3 \mathrm{USD}+\beta 4 * \mathrm{EURO}+\varepsilon 2$

The models above will be estimated by using VAR (Vector Auto Regressive) Specification. VAR models were popularised in Econometrics by (Sims, 1980) as a natural generalisation of univariate autoregressive models. The simplest case that can be entertained is a bivariate VAR, where there are only two variables Y1t and Y2t, each of whose current values depend on different combinations of the previous $\mathrm{k}$ values of both variables, and error terms (Brooks, 2014).

$\mathrm{Y} 1 \mathrm{t}=\beta 10+\beta 11 \mathrm{Y} 1 \mathrm{t}-1+\ldots+\beta 1 \mathrm{kY} 1 \mathrm{t}-\mathrm{k}+\alpha \dot{1} 1 \mathrm{Y} 2 \mathrm{t}-1+\ldots+\alpha \dot{\alpha} \mathrm{Y} 2 \mathrm{t}-\mathrm{k}+\mathrm{U} 1 \mathrm{t}$

$\mathrm{Y} 2 \mathrm{t}=\beta 20+\beta 21 \mathrm{Y} 2 \mathrm{t}-1+\ldots+\beta 2 \mathrm{kY} 2 \mathrm{t}-\mathrm{k}+\alpha \dot{\alpha} 21 \mathrm{Y} 1 \mathrm{t}-1+\ldots+\alpha 2 \mathrm{kY} 1 \mathrm{t}-\mathrm{k}+\mathrm{U} 2 \mathrm{t}$

Where Uit is a white noise disturbance term with $\mathrm{E}(\mathrm{Uit})=0$, (i=1,2), $\mathrm{E}(\mathrm{U} 1 \mathrm{t} \mathrm{U} 2 \mathrm{t})=0$

The existence of a long-term relationship between the variables is tested with cointegration analysis. However, the series involved in the analysis must be stationary at the same level in order to perform Johansen Cointegration Test. If cointegration 
is detected between the series (pension mutual funds/mutual funds and exchange rates), Vector Error Correction Model (VECM) will be used to determine the direction of the relationship.

\subsection{Analysis}

Impact of FX rates (USD/TL and EUR/TL) on 'net asset values of pension funds' (=referred here and after as 'EYF') is analysed. Firstly, unit root analysis is performed in order to make sure that the variables are stationary.

Table 5. ADF Unit Root Test Results (Intercept and Trend)

\begin{tabular}{|l|c|c|c|}
\hline Variables & T-stat & Variables & T-stat \\
\hline LNEYF & -2.148 & $\Delta$ LNEYF & $-9.102^{*}$ \\
\hline LNYF & -2.063 & $\Delta$ LNYF & $-6.067^{*}$ \\
\hline USD & -2.916 & $\Delta$ USD & $-7.365^{*}$ \\
\hline EURO & -2.670 & $\Delta$ EURO & $-7.69 *$ \\
\hline
\end{tabular}

The $*$ indicates significance at $\% 1$ and $* *$ at $\% 5$

In Table 5, Augmented Dickey-Fuller test results indicate that these variables (EUR/TL, USD/TL and 'EYF') are stationary at the $1^{\text {st }}$ difference (that is, FX rates and 'EYF' have no unit root).

Table 6. VAR Lag Order Selection

Endogenous Variables: LNEYF USD EURO

\begin{tabular}{|l|c|c|c|c|c|}
\hline Lag & LogL & LR & FPE & AIC \\
\hline 0 & -61.288 & NA & 0.001497 & 2.009 \\
\hline 1 & 219.321 & 526.142 & $3.08 \mathrm{e}-07$ & -6.479 \\
\hline 2 & 230.048 & $19.108^{*}$ & $2.93 \mathrm{e}-07^{*}$ & $-6.533^{*}$ & $-6.074^{*}$ \\
\hline 3 & 237.007 & 11.743 & $3.14 \mathrm{e}-07$ & -5.824 & -6.468 \\
\hline
\end{tabular}

Endogenous Variables: LNYF USD EURO

\begin{tabular}{|l|c|c|c|c|c|}
\hline Lag & LogL & LR & FPE & AIC & SC \\
\hline 0 & -100.391 & NA & 0.005079 & 3.231 & 3.332 \\
\hline 1 & 147.243 & $464.314^{*}$ & $2.93 \mathrm{e}-06$ & -4.226 & $-3.822^{*}$ \\
\hline 2 & 156.480 & 16.454 & $2.92 \mathrm{e}-06^{*}$ & $-4.234^{*}$ & -3.525 \\
\hline$\underline{3}$ & 158.752 & 3.834 & $3.62 \mathrm{e}-06$ & -4.023 & -3.012 \\
\hline
\end{tabular}

VAR Analysis is performed. Above, 'EYF' variable refers to net asset values of pension funds whereas 'YF' refers to mutual funds; 'EUR' refers to 'EUR/TL' and finally 'USD' refers to 'USD/TL'). Table 6 indicates that for each model appropriate lag length is determined as 2 .

Table 7. Johansen Co-Integration Test Results Trend Assumption: Lineer Deterministic Trend Series: LNEYF USD EURO

\begin{tabular}{l}
\multicolumn{5}{c}{$\mathbf{H}_{\mathbf{0}}$} \\
\begin{tabular}{|l|c|c|c|c|}
\hline Hyphotesis & Eigenvalue & Trace & Critical & Value (0.1) \\
\hline $\mathrm{r}=0^{*}$ & 0.207962 & 27.90825 & 27.06695 & 0.0813 \\
\hline $\mathrm{r} \leq 1$ & 0.157491 & 12.52060 & 13.42878 & 0.1336 \\
\hline $\mathrm{r} \leq 2$ & 0.018168 & 1.210086 & 2.705545 & 0.2713 \\
\hline
\end{tabular}
\end{tabular}

*Trace test indicates 1 cointegration equation at 0.1 significance level

In the Johansen cointegration test, we use one less of the appropriate lag length that we find for the VAR model, which was 2. So, in the cointegration test, the lag order is adopted as 1 . As all the variables become stationary at the 1 st difference, we performed Johansen Cointegration Test. In the Johansen cointegration test, original values are used (not differenced series). As seen in table 7, in Lineer Deterministic Trend Assumption, there is 1 cointegration vector at $10 \%$ significance level for LNEYF USD EUR series. However, for LNYF USD EUR series, there was no cointegration vector in any of the assumptions. The next step is to establish the error correction model for LNEYF USD EUR series (VECM).

Table 8. Vector-Error-Correction Model (VECM)

1 Cointegrating Equation: $\quad$ Log likelihood 231.6334

Normalized cointegrating coefficients (Standard error in parantheses)

\begin{tabular}{|c|c|c|}
\hline LNEYF & EURO & USD \\
\hline $\mathbf{1 . 0 0 0}$ & 1.158997 & -1.617441 \\
\hline & $(0.34900)$ & $(0.41273)$ \\
\hline
\end{tabular}

Table 8 illustrates that in the long run, a one-unit increase in EUR (EUR/TL) causes a 1.158997 unit decrease in LNEYF while a one-unit increase in USD (USD/TL) causes an increase of 1.6117441 units in LNEYF. Hence, in the long run, while USD/TL has a positive impact on LNEYF; EUR/TL has negative impact. 


\subsection{Findings}

Findings indicate that that in the long term, there exists a co-integration relation between FX rates (USD/TL and EUR/TL) and 'net asset values of pension funds' (referred as 'EYF' in the tables); there is a positive relation between variables ('USD/TL' and 'EYF' in Turkey). Nonetheless, with respect to the relation between 'EUR/TL' and 'EYF', -in the long term- there is as inverse relation (the variables are inversely related, 'negative relation'). On the other hand, the econometric analysis shows that there exists no (statistically) significant relation between 'FX rates' and 'net asset values of mutual funds' (in Turkey).

\section{CONCLUSION}

MFs, PFs, REIFs and venture capital investment funds, which are considered as collective investment institutions under Turkish Capital Market Regulation, have recently gained more significance in line with increasing capital market activities in Turkey. This study aims to provide a comprehensive and comparative analysis of these funds and therefore aims to provide up-to-date information regarding regulation and operational structure.

The study covers the period between 2015 and 2021 in Turkey, data for number of funds, net asset values and number of investors are received from official website of Capital Market Board (monthly statistical report).

Furthermore, the impact of FX upon the total asset development of mutual funds and private pension funds is analyzed. With 'VAR' and 'Johansen Co-Integration analysis' and with 'Vector-Error-Correction Model', the impact of FX rates on net asset values of pension funds and mutual funds is examined for the period between 2015-2021 in Turkey. Findings indicate that in the long run, there is a co-integration relation between FX rates (USD/TL and EUR/TL) and 'net asset values of pension funds'; there is positive relation between 'USD/TL' and PFs' net asset values. However, in terms of the relation between 'EUR/TL' and 'pension funds' net asset values', -in the long run- the relation is negative (inverse relation between these variables). On the other hand, the findings of the econometric analysis indicate that no (statistically) significant relation exists between FX rates and net asset values of 'mutual funds'.

Considering all these, it is concluded that operating under collective invesment institutions, MFs, PFs, REIFs and venture capital investment funds have been developing in terms of asset under management. Given the fact that they are relatively new products in Turkey, in the near future, the funds' proportion in total finance will further increase significantly.

\section{REFERENCES}

Akgiray, V., Peksevim, S., \& Şener, E. (2016). Emeklilik Fonları ve Finansal İstikrar. International Journal of Finance \& Banking Studies (21474486), 5(2), 01-20. https://doi.org/10.20525/ijfbs.v5i2.267

Arslan, M., \& Arslan, S. (2010). Yatırım Fonu Performans Ölçütleri, Regresyon Analizleri ve MANOVA Yöntemine Göre A, B ve Borsa Yatırım Fonlarının Karşılaştırmalı Analizi. İşletme Araştırmaları Dergisi, 2(2), 3-20.

Brooks, C. (2019). Introductory econometrics for finance. Geliş tarihi gönderen https://www.cambridge.org/core/product/identifier/9781108524872/type/BOOK

Capital Markets Board of Turkey. (2021, Ağustos 8). Geliş tarihi 08 Ağustos 2021, gönderen https://www.cmb.gov.tr/

Cumming, D., \& Johan, S. (2009). Legality and venture capital fund manager compensation. Venture Capital, 11(1), $23-54$. https://doi.org/10.1080/13691060802351206

Edward, S., \& Daniel, E. (2000). Real Estate Mutual Funds: Abnormal Performance and Fund Characteristics. Journal of Real Estate Portfolio Management, 6(3), 239-247. https://doi.org/10.1080/10835547.2000.12089613

Fazıl, G., \& Günel, M. O. (2012). Türk yatırım fonlarının portföy performanslarının analizi. Ankara Üniversitesi Sosyal Bilimler Dergisi, 3(2), 3-25. https://doi.org/10.1501/sbeder_0000000043

Goren, S., \& Umutlu, M. (2016). Performance Evaluation Of Mutual And Pension Funds Traded On Borsa Istanbul Under The Control Of Fund Costs. Journal of Economics Finance and Accounting, 2(4), 0-0. https://doi.org/10.17261/Pressacademia.2015414371

Kiymaz, H., \& Simsek, K. D. (2017). The performance of US-based emerging market mutual funds. Journal of Capital Markets Studies, 1(1), 58-73. https://doi.org/10.1108/JCMS-10-2017-003

Konuralp, G. (2005). Sermaye Piyasaları: Analizler, kuramlar ve portföy yönetimi. İstanbul: Alfa.

Mayer, C., Schoors, K., \& Yafeh, Y. (2005). Sources of funds and investment activities of venture capital funds: Evidence from Germany, Israel, Japan and the United Kingdom. Journal of Corporate Finance, 11(3), 586-608. https://doi.org/10.1016/j.jcorpfin.2004.02.003

Merkezi Kayıt İstanbul. (2021, Temmuz 15). Geliş tarihi 08 Ağustos 2021, gönderen https://www.mkk.com.tr/tr-tr/Sayfalar/Home.aspx

Samirkaş, Ö. G. mustafa C., \& Düzakin, D. D. H. (2012). Türkiye'deki A Ve B Tipi Yatırım Fonlarının Performans Analizi. Çukurova Üniversitesi Sosyal Bilimler Enstitüsü Dergisi, 21(3), 391-410. Geliş tarihi gönderen https://dergipark.org.tr/tr/pub/cusosbil/60398

Serra Eren Kadığlu. (2018). Portföy Yönetiminde Yeni Yaklaşımlar: Dijital Portföy Yönetimi ve Robo Danışmanlık (1. bs). İstanbul: Nisan Yayınları.

Sevindi, B. S. Y. (2019). Gayrimenkul Yatırım Fonları ve Muhasebe Uygulamaları (1. bs). Kişisel yayın.

Sims, C. A. (1980). Macroeconomics and Reality. Econometrica, 48(1), 1-48. https://doi.org/10.2307/1912017

Temizel, F., \& Bayçelebi, B. E. (2015). Yatirim Fonu Performans Değerlemesinde Güncel Yaklaşimlar Ve Tefas Sonrasi Dönem İçin Türkiye Önerisi. Business and Management Studies: An International Journal, 3(3), 273-289. Geliş tarihi gönderen 
https://app.trdizin.gov.tr/makale/TVRrMU9UUTNOdz09/yatirim-fonu-performans-degerlemesinde-guncel-yaklasimlar-ve-tefas-sonrasi-donemicin-turkiye-onerisi

Uzunoğlu, S. (2020). Bankacıllğa Giriş (2. bs). İstanbul: Literatür Yayınları. Geliş tarihi gönderen http://sadiuzunoglu.com/bankaciliga-girisgenisletilmis/

Uzunoğlu, S., Sönmezler, G., \& Akduğan, U. (2020). Güncel Ekonomik Sorunlar: Ticaret Savaşları. İçinde Güncel Ekonomik Sorunlar Ticaret

Savaşları (1. bs, s. 250). İstanbul: Literatür Yayınları. Geliş tarihi gönderen http://sadiuzunoglu.com/guncel-ekonomik-sorunlar-ticaret-savaslari/ Yay, G. G. (2015). Para ve finans: Teori-politika (2. bs). Geliş tarihi gönderen https://bilgiyay.com/kitap/para-ve-finans-teori-politika/

Zider, B. (1998). How venture capital works. Harvard Business Review, 76(6), 131-139.

https://www.oecd.org/finance/private-pensions/globalpensionstatistics.htm (Access 30 June 2021

TCMA, Turkish Capital Markets 2020 Annual Review

Central Bank of Turkey, Financial Stability Report, 2021 May.

OECD Report, Pension Funds in Figures, June 2021.

https://www.cmb.gov.tr/ (Access 30 June 2021)

https://www.egm.org.tr/homepage (Access 30 June 2021) 